\title{
DELEGATION AND ACCOUNTABILITY IN PARLIAMENTARY DEMOCRACIES
}

\author{
KAARE STRØM \\ Department of Political Science \\ University of California, San Diego \\ 9500 Gilman Drive \\ La Jolla, CA 92093-0521 \\ USA \\ Phone: +1-858-534-0793 \\ Fax: +1-858-534-7130 \\ E-mail: Kstrom@weber.ucsd.edu.
}

\begin{abstract}
Parliamentary democracy has been widely embraced by politicians and especially by the scholarly community but remains less well understood. In this essay, I identify the institutional features that define parliamentary democracy and suggest how they can be understood as delegation relationships. I propose two definitions: one minimal and one maximal (or ideal-typical). In the latter sense, parliamentary democracy is a particular regime of delegation and accountability that can be understood with the help of agency theory, which allows us to identify the conditions under which democratic agency problems may occur. Parliamentarism is simple, indirect, and relies on lessons gradually acquired in the past. Compared to presidentialism, parliamentarism has certain advantages, such as decisional efficiency and the inducements it creates toward effort. On the other hand, parliamentarism also implies disadvantages such as ineffective accountability and a lack of transparency, which may cause informational inefficiencies. And whereas parliamentarism may be particularly suitable for problems of adverse selection, it is a less certain cure for moral hazard. In contemporary advanced societies, parliamentarism is facing the challenges of decaying screening devices and diverted accountabilities.
\end{abstract}

Prepared for presentation at the Conference on "Re-Thinking Democracy in the New Millennium" at the University of Houston, February 16-19, 2000. I am grateful to Torbjörn Bergman, Arthur W. Lupia, Wolfgang C. Müller, and Asbjørn Skjæveland for valuable comments on earlier drafts. Parliamentary democracy is the world's most popular political project. About a third of the world's 
population live under this form of regime, and their numbers have never been greater. By and large, the great majority of those citizens accept parliamentarism as a legitimate vehicle for popular representation. Likewise, among the scholarly community, parliamentary democracy has found widespread support (e.g., Linz and Valenzuela 1994; Moe and Caldwell 1994; Weaver and Rockman 1993). Yet, parliamentarism may be more widely admired than understood. Those who have debated the merits of parliamentary government have generally assumed that although the effects of parliamentarism may not be obvious, its essential features are well defined and understood. This is not necessarily so, however.

One problem has to do, simply, with the adequacy of the terms by which we classify regime types. While most people find it straightforward to categorize Britain as a parliamentary system and the United States as presidential, it is less obvious how we should understand many other constitutions. Moreover, such ambiguities seem to arise particularly with constitutions drafted in recent decades. Increasingly, it seems, it is unclear even to the most careful and professional observer whether or not given systems should be classified as parliamentary.

A second problem concerns the normative standards by which parliamentary and other constitutions have been evaluated. The literature variously cites such criteria as stability, efficiency, representativeness, proneness to military intervention, temporal rigidity, flexibility, dual legitimacies, policymaking capabilities, and others (e.g., Linz and Valenzuela 1994; Shugart and Carey 1992; Weaver and Rockman 1993). While these may all be legitimate concerns, it is not always clear how they should be understood or how they relate to one another. Are these desiderata compatible or mutually exclusive? Do they form an exhaustive catalog of desirable regime properties? And is there a set of first principles for popular selfgovernment from which the various performance criteria could be derived?

In this article, I revisit the nature and consequences of parliamentary democracy. I begin by considering our conventional conception of parliamentarism and some attendant problems. I then suggest an alternative way of thinking about parliamentarism as a mechanism of delegation and accountability and propose two definitions: one minimal and one maximal (or ideal-typical). In the latter sense, parliamentarism is a particular delegation regime, a way to structure the democratic process of representation and decision making, which can be understood with the help of the conceptual apparatus of agency theory. With the help of this set of theoretical tools, I outline several important ways in which we expect parliamentary democracy to differ from presidentialism. I shall not try to determine whether 
parliamentary government is inherently superior or inferior to presidentialism. Indeed, such a judgment cannot be made in general terms, since each regime type represents a particular trade-off among desirable (and less desirable) institutional properties. I shall, however, identify some distinctive properties of parliamentarism and contrast these with other regime types, mainly presidentialism. This discussion will provide some premises on which a judgement of their respective merits could be made. Finally, I address what I believe are two increasingly important challenges facing parliamentarism in the contemporary world: the decay of screening devices and the problem of diverted accountabilities.

\section{PARLIAMENTARISM}

Let us first consider the conventional conceptions of parliamentary government. Note at the outset that, unlike United States federalism or presidentialism, parliamentarism was not the product of deliberate

institutional design, but rather a historical accident of 19 th century Britain. ${ }^{1}$ It has since spread to most of Western Europe and to other parts of the world that have been under British rule or tutelage. When we conceptualize parliamentary government, we are therefore trying to grasp the essence of an historical evolution rather than a deliberate human design.

Two basic ideas are central to conventional understandings of parliamentary government: parliamentary supremacy and the notion of fused, or unified, powers. Whereas the former, the notion that the legislature controls the executive branch and the policy-making process, is today often brushed aside as misleading (see, for example, Laver and Shepsle 1996, pp. 12-13), it is certainly historically important. In its original form, parliamentary government indeed meant parliamentary supremacy, in the majoritarian Westminster tradition (Lijphart 1984). As Verney observed, "the political activities of parliamentary systems have their focal point in parliament. Heads of state, governments, elected representatives, political parties, interest groups, and electorates all acknowledge its supremacy" (Verney 1959: 83). The belief in the unfettered rule by the popularly elected majority lies at the heart of the tradition of parliamentary government. It also implies that the parliamentary front bench is the locus of executive decision making (though not necessarily routine implementation and administration). Moreover, it has been argued that in its pure form, parliamentary democracy means that the members of the core executive (at a minimum, the cabinet ministers) must also at the same time be members of parliament (Lane and Narud 1994). 
Parliamentary supremacy seems strangely at odds with the contemporary realities of parliamentary politics, in which the role of parliament in drafting legislation and budgets appears to be severely circumscribed. As Bagehot already recognized, however, the critical role of parliament lies not in legislation: "The main function of the House of Commons is one which we know quite well, though our common constitutional speech does not recognize it. The House of Commons is an electoral chamber ..." (Bagehot 1990 [1867]: 36). Historically, British parliamentarism emerged simultaneously with the evolution of two cohesive parliamentary parties: a government and an opposition. Over the second half of the nineteenth century, power was increasingly delegated from parliament to the front bench of the majority party, that is to say, the cabinet. The institutional vehicles for the evolution of cabinet dominance were the confidence relationship and the Prime Minister's dissolution power (Cox 1987). As a consequence of such delegation, parliaments at least appeared to suffer a political decline.

Parliamentary supremacy came to mean extensive delegation to the cabinet, resting on the latter's threats of resignation and parliamentary dissolution. These threats in turn assumed and implied two-party politics, which, however, has no longer been typical of parliamentary systems since the introduction of proportional representation. In systems without single-member district elections and two-party systems, parliamentarism has taken different and more consensual forms, in which cabinet coalitions are frequent. In many such coalitional systems, the locus of decision making has shifted from the parliamentary front bench to the party organizations outside the parliamentary channel (see Müller 2000). Correspondingly, parliamentarism has come to be understood as a system of fused, or unified, government. This second conception of parliamentary democracy, which can be traced back to Bagehot (1867), focuses on the dependencies between parliament and the executive branch. Parliamentarism is accordingly defined as that form of constitutional democracy in which executive authority emerges from and is responsible to legislative authority (Lijphart 1984 and 1992). In Shugart and Carey's (1992) terms, in parliamentary systems the origins and survival of the legislative and executive branches are not separated. This emphasis on the interdependence of parliament and cabinet, an emphasis made even more explicit by Stepan and Skach (1993), who define a parliamentary regime as a system of mutual dependence, and a presidential regime as one of mutual independence.

Useful as they are, these definitions are not quite satisfactory. There are three problems: one analytical, the second empirical, and the third theoretical. The analytical problem is that many conventional definitions are operationally ambiguous, as different scholars classify the same political systems differently (see Elgie 
1998). Also, much of the recent literature on regime types has concerned itself with hybrids, such as the French Fifth Republic or Switzerland, that defy the traditional dichotomy. In the former case, the executive does not emerge from the legislature, whereas in the latter it does not depend on the legislature's confidence. How, then, do we categorize France? Is it parliamentarty or presidential? And what about Switzerland? Or Poland? Or Russia? In fact, a growing number of constitutions do not fit the standard definitions. These constitutions, and the French Fifth Republic in particular, have spawned a growing literature on "semi-presidential" or "premier-presidential" government (Duverger 1980; Elgie 1998; Sartori 1997; Shugart and Carey 1992).

The empirical problem is that if emergence is understood to mean some form of active selection, this criterion simply does not very faithfully describe the process of government formation in systems that we conventionally label as parliamentary. It is true that in some such systems, e.g., Ireland, parliament actually elects a prime minister by majority vote. In other systems, such as Italy, parliament must, after a new prime minister has been appointed, approve the incoming cabinet in an investiture vote. In most cases, however, there is simply no mechanism by which parliament directly selects the prime minister and cabinet. Britain, the birthplace of modern parliamentary democracy, has no such institutional vehicle. Nor does Austria, Denmark, Finland, the Netherlands, or Norway, just to name a few (for empirical surveys, see Bergman 1993; De Winter 1995; Laver and Schofield 1990, ch. 4). In the real world, then, parliamentarism rarely means that the legislature actually elects the executive (Beyme 1973: 41-43).

The theoretical problem is that the existing definitions do not tell us much about parliamentary democracy. In other words, our attention is directed toward the balance of power between different branches of government rather than toward the process by which citizens influence public policy. But this is an unfortunate diversion from central concerns in democratic theory. The debate over whether particular constitutions should be defined in one way or another easily appears arcane and arid if it is not related to some explicit concern with popular governance.

The terms parliamentary democracy and parliamentary government are often used interchangeably. I depart from this conventional usage by proposing two distinct and complementary definitions of parliamentarism: one minimal and one maximal (or ideal-typical). A minimal definition should provide the simplest and sharpest tool by which we can distinguish parliamentary systems from others. I shall suggest one that helps solve the analytical problem discussed above. A maximal definition, on the other 
hand, should help us understand the implications for popular rule and governance, in other words, the theoretical problem.

Hence, let parliamentary government refer to the institutional arrangement by which the executive is accountable, through a confidence relationship, to any parliamentary majority. Thus, in our minimal definition, parliamentary government is a system of government in which the prime minister and his or her cabinet are accountable to any majority of the members of parliament and can be voted out of office by the latter (see Steffani 1979), through an ordinary or constructive vote of no confidence. ${ }^{B}$ What characterizes parliamentary democracies is that the cabinet must be tolerated by the parliamentary majority, not that the latter actually plays any direct role in the selection of the former. This preserves half of the conventional definition of parliamentarism, namely the idea of interdependent survival, whereas it disregards the question of origin. Political systems that we conventionally label as parliamentary have much more in common with respect to the former criterion (survival) than with respect to the latter (origins).

It is also not clear that the way a cabinet emerges matters as much as its accountability. As long as the cabinet is responsible to parliament and can be voted out of office by a parliamentary majority, does it much matter how it is selected? Recent theoretical work suggests that the answer is no. Diermeier and Stevenson (1998), for example, argue that it is the confidence relationship, the threat of being voted out of office, that accounts for the fact that parties are more cohesive in parliamentary systems than under presidentialism (see also Huber 1996; Baron 1998). In terms that will be employed later in this article, the decisive property is ex post accountability, and not ex ante selection. In this article, I shall build on these insights and suggest how they may lead us to conceive of parliamentary democracy.

The definition I have suggested provides an effective operational tool whereby we can classify political regimes. Thus, France V is a parliamentary system (which also happens to have a powerful president), whereas Switzerland is not. Note that this classification is consistent with how most observers describe the distribution of power under divided government in France (see, for example, Huber 1996): the Prime Minister's accountability to the National Assembly means that the president's power is much more limited than one might have guessed from accounts of the Fifth Republic written before the first incidence of divided government (cohabitation) in the mid-1980s. Note also that by implication parliamentarism and presidentialism are neither mutually exclusive nor exhaustive. If presidentialism is understood as a regime 
in which the head of state is a president with significant powers who is popularly elected for a fixed term, then the Fifth French Republic is both presidential and parliamentary, whereas Switzerland is neither.

\section{DELEGATION AND ACCOUNTABILITY}

Whereas this conception of parliamentary government is useful for purposes of classification, the theoretical problem calls for a more elaborate conceptualization. Let us begin by considering the policy process in contemporary democracies, from voters all the way to the civil servants that ultimately implement public policy. This is a chain of delegation, in which those authorized to make political decisions conditionally designate others to make such decisions in their name and place. Delegation is common in all sorts of social situations, for example, when individuals consult a medical doctor or a lawyer to help them with medical or legal concerns, respectively. Why do we delegate in political matters? Agency theory, which describes situations in which one party (an agent) acts on behalf of another (the principal) (see, e.g., Lupia and McCubbins 2000; Aghion and Tirole 1997; Kiewiet and McCubbins 1991), tells us that delegation takes place because the agent has certain kinds of information or skills, (e.g., in the form of professional training), or simply time, that the principal lacks. This kind of reasoning applies in politics as well as in other spheres of life. The reason that we do not make all political decisions through direct democracy is for one thing that we simply do not have the time, and secondly that we do not trust our ability to make well-informed and mutually consistent decisions. Hence the rationale for delegation and representative democracy.

\section{The Chain of Delegation}

Representative democracy features a chain of delegation from voters to those who govern, in which we can identify at least four discrete steps:

(1) From voters to elected representatives,

(2) From legislators to the executive branch, specifically to the head of government (the prime minister),

(3) From the head of government (prime minister) to the heads of different executive departments, and

(4) From the heads of different executive departments to civil servants.

This chain of delegation is mirrored by a corresponding chain of accountability that runs in the reverse 
direction. In order to ensure that delegation serves their interests, principals need ways of keeping agents honest. An agent is accountable to his principal if (1) he is obliged to act on the latter's behalf, and (2) the latter is empowered to reward or punish him for his performance in this capacity (Fearon 1999: 55). Thus, democratic constitutions contain mechanisms that allow principals to delegate and that make agents accountable ex post. Indeed, what makes democratic regimes democratic, is precisely that they contain mechanisms by which the people, the ultimate principals in democratic societies, can select and control their representatives.

All representative democracies entail delegation and accountability. Different constitutions imply different delegation regimes. The idea of parliamentary supremacy implies, in the language of agency theory, that, in its relationship with the cabinet and the rest of the executive branch, parliament is the principal, the holder of original authority. The prime minister and his or her cabinet are correspondingly the legislature's agent. Similar agency relationships exist at other links in the chain of delegation. Democracy as popular sovereignty means that ordinary citizens are the ultimate principal.

This view of representative democracy as delegation and accountability is, of course, a simplification in more ways than one. First, note that political agents may be individual or collective, as may principals. Collective principals and/or agents complicate the issues of delegation and accountability. As the ultimate principals, voters face enormous problems of coordination. In most large-scale societies, they cannot possibly actively deliberate over the selection and supervision of their agents. Instead, simple ways have to be found to aggregate their preferences, typically in periodic elections. But as for any large collective, the problems of preference aggregation can make a mockery out of any notion of a popular will expressed through elections (see Arrow 1951; Riker 1982). Even smaller collective principals have their problems. When parliament, for example, acts as a principal, the members are capable of active participation and may find institutional ways to overcome the preference cycles (intransitivities) associated with preference aggregation (Shepsle 1979). But they may still encounter problems of collective action that could hamper their ability to control their agents (Olson 1965). It is thus not clear that collectives without a hierarchical or other institutional structure are capable of acting as principals or agents (see Strøm 1995). Riker (1982) therefore rejected the "populist" vision of democracy in favor of a liberal ideal, in which he sees a much more constrained role for the citizens as principals. In this view, "the function of voting is to control officials, and no more" (Riker 1982: 9. Emphases in the original). Thus, voters cannot actively instruct their representatives, give them mandates, only sanction. Thus, democracy in Riker's view means 
accountability rather than active delegation.

Even if one accepts the idea that legislators and executives have a mandate, there are conflicting visions of what this mandate could be. Many constitutions explicitly designate parliamentarians as representatives of all citizens, and not simply of those that elected them or to whom they are accountable. Though such a constitutional principle is typically unenforceable, it can at least give elected officials a normative justification for acting contrary to the preferences of their voters. And politicians do indeed tend to

embrace this conception of their agency. ${ }^{4}$ Moreover, in liberal democracies, all representatives are bound by constitutional norms that may disallow the representation of certain popular preferences (e.g., racial discrimination, cruel punishment, or confiscatory government takings). Finally, in federal or confederal democracies, representatives may be considered to be agents of the states that make up the union, rather than of the people itself (see Ferejohn 1999). When we nonetheless consider the incumbents of political office as agents of the citizens, we have to acknowledge that they are constrained and frequently common agents, whose responsibilities and accountabilities may thus be manifold.

\section{Parliamentary Democracy}

Building on this framework, we can now spell out the maximal definition of parliamentary democracy and compare it to presidentialism. In its ideal-typical form, parliamentary democracy is a chain of delegation and accountability, from the voters to the ultimate policy makers, that has the following characteristics: 
(1) It is a single chain of delegation with multiple links.

(2) In each link, a single principal delegates to a single or multiple non-competing agents. In a pure form of parliamentary democracy, voters elect a single representative in a unicameral legislature. Members of parliament in turn delegate to a prime minister overseeing an executive branch of ministries with nonoverlapping jurisdictions. In contrast, voters in a presidential system typically elect multiple competing agents. Thus, parliamentary democracy means a particularly simple form of delegation.

(3) In a similar fashion, under parliamentary democracy agents are accountable to a single (though not necessarily individual or unique) principal. Cabinet ministers, for example, report to a single master (the prime minister), and ultimately to a parliament in which a single committee controls their jurisdiction. Likewise, civil servants have a single principal, their respective cabinet minister. This differs from a presidential system in which agents may have multiple principals. Civil servants, for example, may have to report to the president as well as to one or several legislative chambers, and they may also be overseen by the courts or subnational principals. Parliamentary democracy, then, means simple accountability.

The ideal-typical parliamentary democracy thus features a single chain of command, in which at each link a single principal delegates to one and only one agent (or several non-competing ones), and where each agent is accountable to one and only one principal. This singularity principle (single or non-competing agents for each principal; a single principal for each agent) sets parliamentarism apart from other constitutional designs (e.g., United States presidentialism).

\section{(FIGURE 1 ABOUT HERE)}

Figure 1 gives a stylized representation of the chain of delegation under parliamentary democracy, compared with presidentialism of the United States variety. Note the singularity of principals and agents in the parliamentary system, as compared with the more complex relations of delegation and accountability under a presidential model. In the most general sense, the chain of delegation under both constitutional forms approximate the shape of an hour glass. Representation begins with a multitude of principals (the citizens) and ends with a large number of agents (civil servants). In between, however, the parliamentary chain narrows down more than does the presidential one. Specifically, the parliamentary chain narrows down to a single link in which the prime minister connects the elected representatives of the people and the 
administrators of the state. It is thus in the relationship between the legislative majority and the executive that the two regime forms most clearly diverge. Simply put, delegation relationships under parliamentarism take the form of a long and singular chain, whereas under presidentialism they look like a grid.

In reality, of course, the singularity principle is not perfectly legislated or observed, even in countries that fall under our minimal definition of parliamentary government. Two or more agents, such as executive agencies, may compete for the attention of the same principal, for example a particular cabinet member. Or a single agent, such as a prime minister, may see himself as accountable to two or more principals at different stages of the delegation process. For example, the prime minister may at the same time seek to satisfy the parliamentary majority and the popular majority. As I argue below, the latter kind of conflict may be a source of growing strain in parliamentary systems. Yet, the models in Figure 1 capture prominent and important contrasts in constitutional design.

\section{AGENCY PROBLEMS}

Any delegation of authority creates the risk that the agent may not faithfully pursue the interests of the principal. If the agent has interests and incentives that are not perfectly compatible with those of the principal, delegation may generate agency problems. Agency problems arise when the agent acts in ways that are not in the interest of the principal. Agency losses take the form of omission, commonly known as "shirking," when the agent simply fails to act in the best interest of the principal, or commission (sabotage), when the agent takes some positive action contrary to the will or interest of the principal. Agency problems are likely to be exacerbated under hidden information (principals do not fully know the competencies or preferences of their agents or the exact demands of the task at hand) or hidden action (principals cannot fully observe the actions of their agents). The former of these conditions can give rise to problems of adverse selection, the latter to moral hazard. The former of these problems may lead principals to systemically select "the wrong" agents, agents that do not have the most appropriate skills or preferences. The problem of moral hazard, on the other hand, arises when agents, once selected, have incentives and opportunity to take unobservable action that is contrary to the interests of the principal.

\section{Containing Agency Losses}


To safeguard against agency losses, principals engage in various forms of oversight of their agents. The literature on delegation identifies four major measures by which principals can contain agency losses: (1) contract design, (2) screening and selection mechanisms, (3) monitoring and reporting requirements, and (4) institutional checks (Kiewiet and McCubbins 1991). The former two are mechanisms by which principals seek to contain agency losses ex ante, that is, before entering any agreement. Principals may subject potential agents to careful scrutiny and/or insist on retaining as much residual power as possible. Contract design typically seeks to establish shared interests, or incentive compatibility, between principals and agents, e.g., by giving the agent a cut of the principal's gain. Screening and selection represent efforts by the principal to sort out good agents from bad ones before delegating to them. In politics, consider the ways in which parties, for example, help voters screen candidates for public office, or how parliament screens potential cabinet members.

The remaining mechanisms operate ex post. That is to say, they are ways to contain agency losses after the contract has been made. Monitoring and reporting force the agent to share with the principal information that the latter might not otherwise receive. In politics, legislatures require cabinet members to file annual reports, audit their budgets, or summon them to appear in parliament to answer oral or written questions, to furnish documents, or to testify at hearings conducted by regular committees or committees of inquiry (see Mattson and Strøm 1995). Finally, institutional checks subject particularly critical agent decisions to the veto powers of other agents or a third party. As the concept implies, such practices are common in checksand-balances systems.

The choice of oversight mechanisms depends in large part on the nature of agency problems. If the dominant agency problem is adverse selection, then ex ante mechanisms of screening and selection have clear advantages. If, on the other hand, moral hazard is the greatest concern, then there is a stronger case for ex post control. Representative democracy clearly entails problems of adverse selection as well as moral hazard. Fearon (1999) argues that elections should primarily be understood as mechanisms of selecting "good types" for office. That is to say that the dominant agency problem is adverse selection. There can be no doubt that this is indeed a key concern in democratic delegation. But if there is any truth in Lord Acton's famous observation that "power corrupts, and absolute power corrupts absolutely," then voters would be well advised also to consider the problem of moral hazard and the use of ex post sanctions. Though the evidence is soft, Fearon (1999) does in fact cite evidence consistent with the use of elections as sanctioning devices. For example, U.S. Senators from competitive states are more attentive to their 
constituents' preferences than senators with safe seats. And at least in some cases, the evidence that elections are used to sanction politicians is very strong.

Consider the case of U.S. Congressman Dan Rostenkowski. By 1994, the voters of Illinois' Fifth district had elected Rostenkowski to 18 consecutive terms. In two-thirds of those elections, he had won $70 \%$ or more of the popular vote in his heavily Democratic district. Thus, he had risen to the rank of Chairman of the Ways and Means Committee and become the fifth most senior Democrat in the House of Representatives and one of the most influential legislators in the world. Without doubt, Rostenkowski had proven himself overwhelmingly to be the right "type" for his district. Yet, in November 1994 the Fifth district voters, ignoring the personal campaign appearance of President Clinton, decisively rejected Rostenkowski in favor of Michael P. Flanagan, a solidly conservative 31-year-old Republican who had never held any political office. The vote is difficult to interpret as anything but a severe sanction against the incumbent, who had a few months previously been indicted on 17 counts of embezzlement, fraud, and witness tampering. There is little to suggest that the voters prospectively selected Flanagan as the right "type" for the Fifth district -- two years later he went down to defeat by a margin of almost 30 points. Rostenkowski's case is not typical, but it does show that large numbers of voters can be persuaded to cast their votes as a sanction against the past wrongdoings of an incumbent politician. Indeed, this is precisely the function that several formal models attribute to democratic elections (Barro 1973; Ferejohn 1986).

\section{Oversight Under Parliamentary Democracy}

Let us now focus on some features of delegation and oversight that are characteristic of parliamentary democracy. Since oversight is costly, the principal wants to maximize its efficiency relative to its cost. Parliamentary democracy implies a particular choice of instruments to control agent behavior, which systematically differ from those of presidential systems. These institutional choices are implicit in the very definition of parliamentary democracy above. Four features of parliamentary democracy are particularly important:

(1) Compared to presidentialism, parliamentary democracy implies more indirect delegation and accountability, as there are more stages of delegation from voters to ultimate policy makers. Fewer agents are directly elected by, or accountable to, the citizens. In presidential systems, more political offices are typically directly elected by the voters. In the United States, for example, this is true not only of the chief executive at different levels of government (presidents and governors), but also of a variety of other 
executive officers at the state level, such as attorneys general, secretaries of state, education commissioners, insurance commissioners, and others. In parliamentary democracies, citizens have to rely on more indirect chains of delegation and accountability. The challenge is to ensure effective representation across several links in the chain of delegation.

(2) Parliamentary democracy implies a lesser reliance on competing agents. Under presidential systems, voters elect a number of different types of representatives. Similarly, legislators may establish a range of different executive agencies with similar or overlapping jurisdictions. They may in some cases design these institutions in such a way that they can subsequently choose which agents to utilize. In ideal-typical parliamentary democracies, on the other hand, agents are singular, so that no such competition can take place.

(3) Parliamentary democracy implies a lesser reliance on institutional checks. Presidential systems, such as that of the United States, deliberately set up a policy process in which different agents check one another. For example, majorities in both Houses of Congress are required for legislation or budgets to pass. Because of the singularity of agents, parliamentary systems are less likely to have such checks. Therefore, ex post controls, particularly in the form of institutional checks, are less likely to be effective than under presidentialism.

(4) Finally and relatedly, parliamentary democracy implies heavy reliance on ex ante control mechanisms, especially prior screening, relative to ex post accountability. The importance of screening is most evident in the recruitment of cabinet members. In many parliamentary democracies, such as the United Kingdom, law or convention requires cabinet members simultaneously to hold parliamentary office. Thus, the cabinet is a true subset of the parliament. This is largely the case in Westminster parliamentarism, and some observers have seen in this personnel overlap the defining feature of parliamentarism (for example, Hernes and Nergaard 1989). ${ }^{6}$ Even in countries where such requirements do not exist, it is often expected that cabinet members have parliamentary experience (for a cross-national survey, see Andeweg and Nijzink 1995). Quite clearly, the British model greatly facilitates prior parliamentary screening of cabinet members compared to the American one. In the United States, of course, cabinet and legislative office are strictly incompatible, and very commonly, cabinet members have no experience in the national legislature at all. Parliamentary principals thus rely heavily on internal, rather than external, selection of agents. 
The claim that parliamentary democracies deemphasize ex post oversight may at first encounter sound odd, since it is the very existence of ex post cabinet accountability to the parliamentary majority that defines parliamentary government. But the no confidence threat is a blunt and unwieldy instrument, and even presidential systems typically feature some mechanism by which the executive can be removed. Though impeachment is certainly an even more drastic measure than a no confidence vote, it has in recent years been used not only in the United States, but also in Latin American presidential systems such as Argentina and Venezuela. In most parliamentary systems, the impeachment procedure has fallen into disuse. Recall provisions, which feature in some presidential constitutions, are essentially unknown under parliamentarism.

Yet the main problem is not that parliamentary systems lack the opportunity to sanction, but rather that they do not have monitoring capacity necessary to determine when such sanctions might be appropriate. Presidential constitutions tend to feature institutions that facilitate active legislative oversight, of either the police-patrol or the fire alarm variety (McCubbins and Schwartz 1984). Such institutions are much less prominent, and have much less teeth, in most parliamentary systems. Parliamentary committees, for example, have much lower oversight capacity, and in the classical Westminster model, this capacity is almost entirely absent (see Mattson and Strøm 1995). Moreover, the indeterminacy of election dates makes ex post electoral accountability more complicated under parliamentarism. Most, though not all, parliamentary democracies feature some provision for early parliamentary dissolution. In the Westminster model and many other forms of parliamentarism, the election date is fully controlled by the prime minister and his or her party. Consequently, this dissolution power can be used strategically for partisan purposes, and the evidence suggests that such manipulation does in fact occur (Strøm and Swindle, n.d.). The manipulability and unpredictability of election dates reduces the effectiveness of ex post electoral accountability.

Yet, the most important reason that parliamentarism tends in the direction of screening, rather than ex post accountability, lies in the greater prominence of political parties. The institutions of parliamentarism empower political parties to an extent that is not generally found under presidentialism. Under parliamentary democracy, parties control delegation from voters to representatives, as well as from representatives to the chief executive (see Müller 2000). Party control means extensive screening of prospective parliamentarians as well as potential cabinet members. The stronger the "partyness" of society, the more parties have represented distinct social groups, the more they have tended to rely on prior 
screening mechanisms of various sorts.

Before we consider the consequences of these differences in constitutional design, note one caveat. To some extent, the contrasts drawn up in points 2 and 3 reflect different varieties of presidential democracy. The argument made in point two envisions multiple agents as mutually competitive, whereas in point three they are understood as mutual checks. In reality, multiple agents can be either competitive or mutual checks, but not both at the same time. If the policy process permits agent competition, for example, by having different executive agencies compete for the right to implement policy, then these agents cannot simultaneously check one another. If on the other hand, strong institutional checking (veto) powers are vested in agencies that serve the same principals, then these agencies are not truly competitive in the sense that the principal can favor one and ignore the other. Of course, real-world constitutions may feature some combination of competition and checks, which would imply a mix of the features identified under points 2 and 3.

\section{CONSEQUENCES OF PARLIAMENTARY DEMOCRACY}

Let us now turn to the consequences of parliamentary democracy. One purpose of the technical language by which I have defined parliamentary democracy is to describe a lot of apparently dissimilar phenomena and relationships in a common set of terms. A further advantage of this particular language of delegation and accountability is that it permits us to generate rather precise expectations about the effects of different institutional arrangements. This is because agency relationships over the past 20 years or so have been the subject of rigorous analysis by economists and other students of organizations. Institutional arrangements have systematic and predictable consequences. In the present context, we can define these in terms of the dangers of hidden information and action and the effectiveness of the various remedies.

Elsewhere in this issue, Lupia and McCubbins (2000) identify the conditions under which delegation is problematic and may turn into abdication. The theoretical literature on delegation tells us that differences in representative institutions have consequences for the likelihood that the behavior of the agents will be what the principal would have chosen, given the same information as the agent. We can describe deviations from from this conditions in terms of agency loss. The more the actions of the agent diverge from what an equally well informed principal would have done, the greater the agency loss. As the 
delegation models have shown, various parameters of delegation relationships can powerfully affect the agency loss that may occur. The ideal-typical organization of parliamentary democracy has a number of consequences for democratic delegation.

\section{The Virtues of Simplicity}

Following the literature on agency, the simplicities of parliamentary democracy generate a set of discernible advantages compared to the competitors, mainly presidentialism. First, parliamentary democracy implies potential advantages in administrative efficiency. The fact that each agent faces a single principal means that agents are less likely to face conflicting demands than under presidentialist or other multiple-principal systems. One consequence in turn may be that the parliamentary systems that approximate this type exhibit a greater degree of administrative efficiency than presidential systems. These expectations are consistent with the argument of Terry Moe and Michael Caldwell (1994), who note that environmental legislation has been much more successful, and environmental administration much more cost-efficient, under British parliamentarism than under United States presidentialism.

One reason why the simplicity of parliamentary democracy can be beneficial lies in the effort that the institutions induce among principals and agents alike. The theoretical literature on delegation tells us that differences in representative institutions affect the effort that agents put into their tasks and that principals put into monitoring the agents. Agents may assert greater effort when they are given more latitude, since they are thereby provided greater opportunities to realize their own goals with their own chosen means. As long as these preferences do not deviate greatly from the public interest, this may be a good thing. For example, to the extent that the task of cabinet ministers is to find technically efficient solutions to commonly agreed problems, extensive oversight and constraint by multiple principals is probably a bad idea. Similarly, the institutional simplicity of parliamentary democracy may enhance the principals' incentive to exert effort in monitoring agents. If such oversight allows the principal, for example, the members of a particular parliamentary committee, to claim exclusive credit, and if their efforts to control their agents, for example, particular executive agencies, are not thwarted by other "overseers," then we should expect these principals to put more effort into their constitutional responsibilities. Hence, parliamentary democracy is at an advantage in providing incentives for principals to monitor and for agents not to shirk.

These expectations seem to be borne out by the case of Nigeria. When Nigeria returned to civilian rule in 
1979, after 13 years of military government, it changed from a parliamentary to a presidential constitution that included numerous checks and balances. Hence, the country offers a relative rare natural experiment of a change in regime type. Whereas the First Republic had allowed the majority to run roughshod over the opposition, the legislature of the Second Republic quickly became embroiled in legislative gridlock and ineffectiveness. Much to the chagrin of Nigerian citizens, their politicians increasingly turned to “opportunistic and self-interested behavior" (Diamond 1988: 52), in other words, leisure-shirking (or worse).

\section{Constraint and Competition}

Just as parliamentary democracy has certain identifiable advantages over its competition, so too are there particular perils associated with this regime type. The main problems of this sort lie in the singular and indirect chain of accountability and in the less generous provision of information that results. The fact that parliamentary democracies makes use of more indirect, multi-stage, delegation schemes increases the likelihood of overall agency loss. As Geddes (1994) has argued, a singular chain of delegation is only as strong as its weakest link (see also Lupia and McCubbins 2000). If legislators, for example, are poor agents of their voters, then it may not at all be desireable to make civil servants maximally accountable to such elected officials. This is true at least as long as agents do not compete for the favor of their principals. In other words, if principals can bypass a particular link in the chain of delegation, then agency losses in that link are less critical. But what characterizes parliamentary democracy is precisely that such competition does not occur and that principals therefore cannot bypass their agents. Now, it may happen that dissent-shirking by one agent is offset by the actions of another agent further down the chain of delegation. However, the institutions of parliamentary democracy offer no general way to assure such happy outcomes. Moreover, there is generally no way in which leisure-shirking (failure of effort) by one agent can be offset by another agent further "downstream." Therefore, severe agency loss at any stage of delegation is a particularly serious concern under parliamentarism.

The flip side of simplicity is that parliamentarism induces a lesser amount of constraint and competition on agents. Hence, parliamentarism suffers compared to more complex systems of delegation with respect to the salutary effects that competition and containment may have. Note once again, however, that multiagent systems offer some choice between competition and constraint, but that no system can offer the full advantages of both simultaneously. If multiple agents exist and compete with one another, then we may realize the benefits of competition, but not those of institutional checks. Conversely, if each agent 
exercises veto power over the others, then they can generate constraint but not the rewards of competition. Thus, although it is beyond the scope of this analysis, the balance between competition and constraint is an aspect of presidentialism that deserves further consideration.

Constraint and competition matter in part because they affect the principal's ability to learn from the agent's behavior. The more principals can learn, of course, the greater confidence they can have in their agents, and the lesser the likelihood of agency loss. Learning is particularly important dynamically, if principals begin with very incomplete information and attempt to acquire such information from their agents. The informational perspective on legislative organization stresses some of the preconditions for effective political learning. Gilligan and Krehbiel model the relationship between legislatures and their committee members as a signaling game, in which committee members invest resources in specialization and information acquisition and then use their private information to advise the non-specialist members (the floor) concerning the quality of pending proposals. The more heterogeneous the preferences of the committee members, the greater the confidence the floor members can have in the signals that the committees send. Thus, learning improves with the diversity of the sources of information available to the legislators (Gilligan and Krehbiel 1989; Krehbiel 1991). These lessons can be generalized to the agency relationships we are considering here. Generally speaking, because they feature multiple agents with potentially divergent preferences, presidential constitutions are more likely to feature the conditions under which principals can rely on the signals they receive from their respective agents, at least insofar as these agents send convergent signals. Under parliamentary systems, all else equal, principals (e.g., parliamentarians) are less likely to be able to rely on the information fed to them by their agents.

\section{Adverse Selection versus Moral Hazard}

Neither parliamentary nor presidential constitutions can effectively safeguard against all agency problems. As long as principals and agents differ in their preferences and information, some agency losses have to be expected. Yet, whether the typical agency problems are adverse selection or moral hazard bears on, and may be affected by, the choice of political institutions. Recall that parliamentary democracy tends to place a greater reliance on ex ante control mechanisms, especially prior screening, relative to ex post sanctions. This is reflected first and foremost in the internal (parliamentary) recruitment of cabinet members. A second and related manifestation is the greater reliance on parties as screening devices, especially in the first few links in the chain of delegation (see Müller 2000). Parties tend to be more cohesive and play a stronger role in screening in parliamentary systems than they do under presidentialism. Consequently, 
parliamentary regimes may be better equipped to deal with problems of adverse selection. To the extent that the main problem in politics is to select the right "type" of representative, the advantages should lie with regimes that devote more resources to the prior screening of candidates, as is the nature of parliamentarism. At the same time, the weaker capacity for ex post monitoring leaves parliamentarism more exposed to moral hazard. Thus, the institutions characterize parliamentary democracy may safeguard against one agency problem, adverse selection, at the expense of another, moral hazard.

\section{Multiparty Parliamentary Democracy}

The fact that not all systems of parliamentary government are equally close to the ideal type of parliamentary democracy means that we could use this conceptual apparatus to make systematic distinctions between them and to link such distinctions to differences in their dynamics and performance. Indeed, the literature suggests that differences among parliamentary regimes may be as important as differences between parliamentary and presidential ones. For example, in their first tier of institutional differentiation, Weaver and Rockman (1993) differentiate between parliamentarism and presidentialism, but then divide parliamentary systems into three different subtypes. The key to this differentiation is the partisan composition of governments, which in turn is driven by differences in electoral systems.

Tsebelis (1995: 292) goes even further in arguing that with respect to the capacity for policy change, "the logic of decision making in presidential systems is quite similar to the logic of decision making in multiparty parliamentary systems." The critical variable, according to Tsebelis, is not regime type but the number of veto players. All else equal, the larger the number of veto players, the lower the capacity for policy change. Thus, even more strongly than Weaver and Rockman, Tsebelis argues the importance of distinguishing between two-party and coalitional parliamentary systems. Contrary to the former, he goes on to claim that the multiple veto players of coalitional multi-party parliamentary democracies generate policy making dynamics akin to presidential systems.

Although Tsebelis thus identifies intriguing similarities between presidentialism and multi-party parliamentarism, the distinction remains important for our purposes. First, note that under parliamentarism, multiple players can only be checking (i.e., veto), but hardly competing, agents. Thus, multiple agents under parliamentarism take on only one of the two possible roles that they can have under presidentialism. Moreover, although parliamentarism may feature multiple agents with significant policy influence, they are not always veto players, strictly speaking. Tsebelis distinguishes between institutional 
(legislative chambers, presidents, courts, etc.) and partisan veto players (the various parties represented in the cabinet). He acknowledges that the vetoes of institutional veto players are enforceable in ways that those of partisan veto players are not. If one party in a coalition government, for example, refuses to go along with a particular policy proposal, there is no constitutional provision to prevent the rest of the governing parties to pass the bill anyway, provided they can gather enough support on the floor of parliament. Tsebelis argues that the dissenting party can effectively prevent such outcomes by threatening to withdraw from the coalition and thus exposing the government to dismissal or the need to renegotiate. While there is no doubt that such a scenario may in many cases deter a parliamentary majority from "rolling" a dissident coalition partner, it is far from obvious that all coalition parties have this option. Some coalition partners can credibly threaten to resign, because they are pivotal and have other potential coalitions that they could join. But others are not so privileged, for example if they are surplus parties in an "oversized" coalition, or if their policy preferences are relatively extreme. One might think that the fact that majority-preferred bills are rarely passed against the votes of any governing parties demonstrates that such threats somehow can be made credible in most circumstances. But this outcome is observationally equivalent to two other equilibria: one in which the governing parties anticipate all such issues and build them into an logroll in their coalition agreement, and a second in which the dissident parties simply

anticipate their defeats and refrain from breaking coalition discipline in a losing cause. ${ }^{\square}$ It may therefore be that coalition parties observe the niceties of consensus politics even when they are not veto players.

More generally, it is misleading to treat institutional and partisan veto players additively, since parties and the institutions in which they operate are not mutually independent, but rather highly interdependent. A credible veto player must have both opportunity and motive to exercise his or her veto. Partisan veto players may have motive (although that is not always obvious), but they do not generally have opportunity. Institutional veto players by definition have opportunity, though not necessarily motive. Interestingly, Tsebelis (1995: 310) discounts institutional veto players that have no discernible motive, i.e., when their preferences are identical to those of other veto players, for example, in congruent bicameral legislatures. The same treatment should be accorded to partisan players that have no demonstrable opportunity to exercise a veto.

\section{Reversion Points and Policy-Making Transparency}

Yet, multiparty parliamentary systems typically have more influential players (i.e., parties with significant bargaining power), even if these parties are not necessarily veto players. There are two important respects 
in which coalitional parliamentarism may consequently differ from the two-party variety. These have to do with the effects of differences in reversion points and policy-making transparency, respectively. To the extent that coalitional parliamentary systems differ from the two-party variety, we should also expect them to differ in one area highlighted by Lupia and McCubbins in this issue: the attractiveness of the reversion point. Reversion points can matter a great deal. The more attractive the reversion point is to the principal, the less likely it is that he will accept proposals that are far from his ideal point. On the other hand, when the reversion point is unattractive, the principal may accept proposals that are far more remote from his own preferences.

Under what institutional conditions are reversion points likely to be unattractive to the democratic principal (here: the voters)? One such situation might be where successive governments have quite different policy preferences, perhaps because they were elected under „decisive“ (e.g., single-member) electoral systems that magnify shifts in popular preferences and tend to foster two-party politics. Undesirable reversion points could also be the result of institutional structures that induce policy stability. If popular preferences shift over time, then systems that contain numerous influential players will tend to have less desirable reversion points than those in which there are fewer veto players.

These two factors, electoral rules and veto players, do not correlate highly with parliamentarism and often have offsetting effects. Parliamentary systems generally have fewer influential players than presidential ones, which could help reduce the likelihood of unattractive reversion points. Yet, some parliamentary constitutions actually have a considerable number of veto players, due to federalism or other power-sharing constitutional features (e.g, Belgium or Germany). And the parliamentary systems with the fewest veto players (the Westminster systems) tend to have electoral systems (SMDP) most likely to produce unattractive reversion points.

Under coalitional parliamentarism, the mutual accommodation of the governing parties requires more and different compromises than when a single party controls the cabinet. But compared to presidentialism the requisite bargaining and accommodation is less transparent. Bargaining takes place behind close doors in cabinet or in coalition committees or summits, rather than in the form of proposals and counter-proposals that are shuttled back and forth between different branches of government. Thus, political bargaining is displaced from a public to a private arena, where it will be less informative to the political principals. The more political bargaining is played out in relatively open fora such as legislatures, the greater the prospects 
for transparency. The more, on the other hand, politics is confined to the sphere of ,invisible politics“ (Sartori 1987), to private negotiations within political parties, or within government coalitions, the less transparent the policy process will tend to be, and the more uncertainty voters may have about their representatives. Parliamentary systems generally score lower on transparency than presidential ones. Thus, multi-party parliamentary politics does not translate directly into the same kind of checks and balances that presidentialism typically features. Specifically, it does not offer the same benefits of competition and information revelation that may be produced under some forms of presidentialism. Multiparty parliamentarism thus sacrifices some of the parliamentary virtues of simplicity without reaping the informational gains of presidentialism.

\section{TWO CONTEMPORARY CHALLENGES}

Thus, parliamentary democracy has both characteristic strengths and weaknesses compared to presidentialism. Parliamentary systems have two salient advantages: they have lower decision costs, and they are more to likely to promote a desirable level of effort on the part of agents. One fundamental strength of parliamentarism lies in its efficiency of operation. Also, strong screening devices protect against adverse selection problems. The weakness, on the other hand, lies in the ability of principals to acquire information concerning the agents' behavior and thereby to learn from their behavior in office. Parliamentary democracies tend to have less transparent politics, which in turn causes information uncertainty among the voters and their immediate agents. Presidential systems, on the other hand, have their own advantages: through containment and competition they protect particularly well against the problems of moral hazard. Which system is superior? There is no general and timeless answer to this question. Rather, the choice between constitutional designs implies a weighing of competing virtues of representation. Moreover, since real-world constitutions themselves may constitute some compromise between the principles of parliamentarism and presidentialism, the choice between these virtues is far from straightforward.

So far I have discussed the merits and demerits of parliamentary democracy in general and timeless terms. My final comments, however, will be on two important challenges facing parliamentary democracies in the contemporary world. These challenges are (1) the decay of screening devices, and (2) the problem of diverted accountabilities. The first problem generally has to do with the ex ante side of delegation, 
whereas the second concerns ex post accountability. Both are challenges driven by broad-based changes in mass preferences in modern democracies, and both present themselves particularly acutely within parliamentary systems. I discuss them successively.

\section{The Decay of Screening Devices}

Parliamentary democracy relies heavily on ex ante controls. Internal delegation, for example, implies reliance on ex ante forms of screening and selection. In the electoral arena, this may take the form of careful party screening of candidates and great attention to ascriptive social representation. In the parliamentary arena, it means that leaders are chosen on the basis of experience, copartisanship, and seniority. In short, principals use internal delegation and ex ante screening to select agents who share as many preferences as possible and about whom the principals have the best possible information. Such mechanisms are most likely to be effective when the agents' abilities and preferences are readily observable or predictable from previous experience. That may in turn mean that parliamentarism is most suitable in small, homogeneous, and stable societies in which principals can have faith in their screening procedures. But such mechanisms may lose their usefulness if prior experience becomes less critical for the tasks at hand, and if ascriptive criteria (e.g., ethnicity or class background) provide fewer cues than previously about the preferences and skills of potential agents. In short, information decay can destroy the effectiveness of ex ante screening.

This is precisely what is happening in contemporary democracies, and it is a trend of which voters may be intuitively aware. Ascriptive information and prior experience provide less useful cues about political agents than they once did, and whatever value such criteria convey diminishes much more rapidly. Class voting, as well as voting along other ascriptive lines (e.g., ethnicity, faith, language, or race), is generally in decline (Dalton 1996). It seems that such ascriptive characteristics give contemporary voters less of the information that they use to make their voting decisions. At the same time, voters are more willing to support candidates who do not have the traditional credentials for a political career. At least, they seem increasingly willing to elect representatives, such as H. Ross Perot or Jesse "the Body" Ventura in the United States, or Silvio Berlusconi in Italy, who have not gone through the traditional screening process (see Strøm 1997). Even British Prime Minister Tony Blair was remarkable in having no previous cabinet experience when he became prime minister.

Another problem with ex ante screening is the increasing volatility of the political agenda. The more the 
future political agenda can be expected to resemble the past, the more faith we can have in ex ante mechanisms of agent screening. But there can be no question that the assumption that the political tomorrow will look like today is becoming less and less tenable as the pace of social change quickens and as information decays more quickly. Information decay, then, is undermining the effectiveness of traditional mechanisms of agency control in parliamentary democracies.

If traditional mechanism of ex ante agent control are thus breaking down, the resulting agency loss may be particularly severe under a parliamentary system. To be sure, such problems may be remedied through greater reliance on various ex post mechanisms, and there is evidence that parliamentary systems are increasingly empowering parliamentary committees and judicial institutions for such purposes (see Mattson and Strøm 1995). If these reforms succeed, they may modify the system in a direction that leads away from the ideal-typical model of parliamentary democracy and introduces some features more akin to presidentialism. However, such reforms focused on greater ex post accountability may not be successful, either because they are untried and or because they conflict with other features of parliamentary democracy.

\section{The Problem of Diverted Accountabilities}

Parliamentarism not only denotes singularity; it also implies indirect delegation. Voters in parliamentary systems delegate to parliamentarians, who in turn delegate to members of the cabinet. Similarly, accountability is indirect, in that cabinet members are accountable to members of parliament, who in turn answer to the voters. This indirect accountability is currently breaking down, in the following way:

As electoral volatility increases, politicians have greater and greater incentives to try to anticipate the voters' reactions and to behave in such a way as to please them, even when elections are not imminent. This responsiveness to the voters can, however, cause politicians to have divided loyalties. As agents, they may try to serve several competing principals at the same time. Thus, when party leaders negotiate over government formation or termination, they no longer try to anticipate only the reactions of the parliamentarians, but also those of the voters. They avoid particular actions not only if they fail to satisfy the parliamentary majority, but also if they fail to find favor with most voters. The idea is that the voters should be consulted, or at least that their opinions should be considered, before changes in government composition take place. 
Two examples may illustrate this tendency. The first and more specific of these has to do with the behavior of Norwegian Prime Minister Thorbjørn Jagland in 1997. Prior to the September 1997 parliamentary election, Jagland declared that his Labor Party government would resign if the party received less than $36.9 \%$ of the national vote, regardless of the parliamentary distribution of power. The election, which gave the party $35.0 \%$ of the national vote, therefore effectively eliminated Labor from consideration and indirectly installed a centrist minority government with only about $25 \%$ of the parliamentary seats behind it. For the first time, Labor had precluded itself from power in a situation in which it might well have been able to form a viable government. Had Jagland not committed himself to his game plan, he most likely could have continued in office after the election. Instead, bargaining over government formation was constrained by his pledge and led to the formation of a cabinet with very shaky parliamentary foundations. In a sense, Jagland's accountability to the voters conflicted with his accountability to the parliamentary majority. The voters won, with results that complicated parliamentary decision making in the years that followed.

The second and more general example is a norm that has since the 1970s developed in the Netherlands and that may be establishing itself elsewhere as well. In Dutch politics, it has become established practice that no new coalition can form unless it has been ratified by the voters through a dissolution of parliament and new elections. No longer is it acceptable for one coalition to depart in the middle of a parliamentary term and for another government simply to replace it. This norm has developed in the absence of any formal rule to that effect (Timmermans and Andeweg 1997: 453). There is no constitutional requirement in the Netherlands, or in most other parliamentary states, that a government resignation must be followed by a dissolution of parliament. Indeed, if the simple accountability of parliamentary democracy were in effect, there should be no need for such a drastic action. The cabinet is accountable only to the parliamentary majority, and it is the task of the latter, not the voters, to generate a new government. Nevertheless, such renegotiation without the involvement of the voters is becoming more and more rare. Why?

The answer may lie in the anticipated wrath of the voters, in the politicians' expectation that the voters expect to be consulted and will punish those who ignore them. The trend toward greater reliance on parliamentary dissolution also parallels what happened in Britain during the evolution of parliamentary government (Cox 1987). But this trend toward greater electoral responsiveness generates a good deal more complexity in a multiparty coalition system. It makes prime ministers accountable to several principals and thus destroys the simplicities of representation that typify parliamentarism. For better or worse, the 
proliferation of principals makes parliamentarism more akin to presidentialism.

\section{CONCLUSION}

Parliamentary democracy can and should be understood as a particular way to organize the policy process, as a delegation regime. As an ideal-typical form of government, parliamentary democracy has a number of distinctive properties. It is simple, it is indirect, and it relies on lessons gradually acquired in the past. This has certain advantages compared to presidentialism or other regime types. The most important ones are decisional efficiency and the inducements parliamentarism creates toward effort. Given these advantages and the fact that so many political theorists and observers recommend parliamentarism, what accounts for the fact that most new constitutions in emerging democracies are either presidential, or contain some mixture of parliamentary and presidential features? Moreover, why have some established parliamentary systems (France in 1958, Israel in 1992) adopted distinctly presidential modifications? What accounts for the fact that constitution makers, judging by their decisions, seem to regard presidentialism so much more favorably than political scientists? Obviously, the answer may lie in the peculiar disadvantages that parliamentary constitutions also have, such as informational inefficiencies and lesser benefits from constraint and competition. These weaknesses particularly expose parliamentarism to problems of moral hazard.

The choice between parliamentary and presidential government involves a choice of mechanisms designed to induce politicians to act in the public interest. While there is no universally compelling way to resolve such trade-offs, the accountability mechanisms specifically associated with parliamentarism are increasingly challenged by important trends in contemporary democratic politics, such as information decay and increasing electoral volatility. Disconcertingly, some of the traditional advantages of parliamentarism are being undermined as the pace of social change quickens, and as the deference of ordinary citizens to their governors declines.

Thus, while parliamentarism has served many societies (and particularly Western Europe) well, the future could well belong to different constitutional arrangements. Yet, the challenges to parliamentary democracy need not be beyond our capacity for political engineering. Nor is it obvious that parliamentarism is necessarily inferior to other forms of democratic governance, even under its growing contemporary strains. 
What seems clear, however, is that the challenges to parliamentary democracy are real, that they are likely to get more, rather than less, acute, and that they deserve to be taken seriously.

\section{References}

Aghion, Philippe and Jean Tirole. (1997). "Formal and Real Authority in Organizations." Journal of Political Economy 105: 1-29.

Andeweg, Rudy B., and Lia Nijzink (1995). "Beyond the Two-Body Image: Relations Between Ministers and MPs.” Pp. 152-78 in Parliaments and Majority Rule in Western Europe, ed. Herbert Döring. New York: St. Martin's Press.

Arrow, Kenneth J. (1951). Social Choice and Individual Values. New York: John Wiley.

Bagehot, Walter (1990). "The House of Commons." In Legislatures, ed. Philip Norton. Oxford: Oxford University Press. Original edition 1867.

Baron, David P. (1998). "Comparative Dynamics of Parliamentary Governments." American Political Science Review 92, 3, 593-609.

Barro, Robert J. (1973). "The Control of Politicians: An Economic Model.” Public Choice 14: 19-42.

Bergman, Torbjörn (1993). "Formation Rules and Minority Governments." European Journal of Political Research $23,1,55-66$.

Beyme, Klaus von (1973). Die Parlamentarischen Regierungssysteme in Europa. Munich: Piper.

Cox, Gary W. (1987). The Efficient Secret. Cambridge: Cambridge University Press.

Dalton, Russell J. (1996). Citizen Politics: Public Opinion and Political Parties in Advanced Western Demcracies. Second edition. Chatham, NJ: Chatham House.

De Winter, Lieven (1995). “The Role of Parliament in Government Formation and Resignation." Pp. 115-51 in Parliaments and Majority Rule in Western Europe, ed. Herbert Döring. New York: St. Martin's Press.

Diamond, Larry (1988). "Nigeria: Pluralism, Statism, and the Struggle for Democracy.” Pp. 33-91 in Democracy in Developing Countries, eds. Larry Diamond, Juan J. Linz, and Seymour Martin Lipset. Boulder, CO: Lynne Rienner.

Diermeier, Daniel and Timothy J. Feddersen (1998). "Cohesion in Legislatures and the Vote of Confidence Procedure." American Political Science Review 92, 3, 611-21.

Duverger, Maurice. (1980). “A New Political System Model: Semi-Presidential Government.” European Journal of Political Research 8: 165-87.

Elgie, Robert (1998). “The Classification of Democratic Regime Types: Conceptual Ambiguity and Contestable Assumptions." European Journal of Political Research 33, 2, 219-38.

Esaiasson, Peter, and Sören Holmberg (1996). Representation from Above: Members of Parliament and 
Representative Democracy in Sweden. Aldershot: Dartmouth.

Fearon, James D. (1999). "Electoral Accountability and the Control of Politicians: Selecting Good Types versus

Santioning Poor Performance.” Pp. 55-97 in Democracy, Accountability, and Representation, eds., Adam

Przeworski, Susan C. Stokes, and Bernard Manin. Cambridge: Cambridge University Press.

Ferejohn, John (1986). "Incumbent Performance and Electoral Control." Public Choice 50: 5-25.

Ferejohn, John (1999). “Accountability and Authority: Toward a Theory of Political Accountability.” Pp. 131-53

in Democracy, Accountability, and Representation, eds., Adam Przeworski, Susan C. Stokes, and Bernard

Manin. Cambridge: Cambridge University Press.

Finer, Samuel E., ed. (1975). Adversary Politics and Electoral Reform. London: Wigram.

Geddes, Barbara (1994). Politician's Dilemma: Building State Capacity in Latin America. Berkeley: University of California Press.

Gilligan, Thomas, and Keith Krehbiel (1989). "Asymmetric Information and Legislative Rules with a

Heterogeneous Committee." American Journal of Political Science 33, 459-490.

Hernes, Gudmund and Kristine Nergaard (1989). Oss i mellom. Oslo: FAFO.

Huber, John D. (1996). Rationalizing Parliament. Cambridge: Cambridge University Press.

Kiewiet, D. Roderick and Mathew D. McCubbins (1991). The Logic of Delegation. Chicago: University of Chicago Press.

Krehbiel, Keith (1991). Information and Legislative Organization. Ann Arbor: University of Michigan Press.

Lane, Jan-Erik, and Hanne Marthe Narud (1994). "Maktfordelingsprinsippet og den konstitusjonelle teori:

Spørsmålet om bemanning av statsmaktene.” In Bjørn Erik Rasch and Knut Midgaard (eds.), Representativt demokrati. Oslo: Universitetsforlaget.

Laver, Michael and Norman Schofield (1990). Multiparty Government: The Politics of Coalition in Europe. Oxford: Oxford University Press.

Laver, Michael J. and Kenneth A. Shepsle (1996). Making and Breaking Governments. Cambridge: Cambridge University Press.

Lijphart, Arend (1984). Democracies: Patterns of Majoritarian and Consensus Government in Twenty-One Countries. New Haven: Yale University Press.

Lijphart, Arend, ed. (1992). Parliamentary versus Presidential Government. Oxford: Oxford University Press.

Linz, Juan J. and Arturo Valenzuela. (1994). The Failure of Presidential Democracy. Baltimore: The Johns Hopkins University Press.

Lupia, Arthur, and Mathew D. McCubbins (2000). "Representation or Abdication: How Citizens Use Institutions to Help Delegation Succeed.” European Journal of Political Research 37, this issue.

McCubbins, Mathew D., and Thomas Schwartz (1984). "Congressional Oversight Overlooked: Police Patrols versus Fire Alarms. American Journal of Political Science 28: 165-79.

Mainwaring, Scott (1990). "Presidentialism in Latin America: A Review Essay." Latin American Research Review 
$25,1,157-79$.

Mattson, Ingvar and Kaare Strøm (1995). "Parliamentary Committees.” Pp. 249-307 in Parliaments and Majority Rule in Western Europe, ed. Herbert Döring. New York: St. Martin's Press.

Moe, Terry M. and Michael Caldwell (1994). "The Institutional Foundations of Democratic Government: A Comparison of Presidential and Parliamentary Systems." Journal of Institutional and Theoretical Economics 150/1, 171-195.

Müller, Wolfgang C. (2000). "Political Parties in Parliamentary Democracies: Making Delegation and Accountability Work." European Journal of Political Research 37, this issue.

Olson, Mancur, Jr. (1965). The Logic of Collective Action. Cambridge, MA: Harvard University Press.

Riker, William H. (1982). Liberalism Against Populism: A Confrontation Between the Theory of Democracy and the Theory of Social Choice. San Francisco: W. H. Freeman.

Sartori, Giovanni (1987). The Theory of Democracy Revisited. Chatham, NJ: Chatham House.

Sartori, Giovanni (1997). Comparative Constitutional Engineering. Houndmills: Macmillan.

Shepsle, Kenneth A. (1979). "Institutional Arrangements and Equilibrium in Multidimensional Voting Models.” American Journal of Political Science 23, 1, 27-59.

Shugart, Matthew S. and John Carey (1992). Presidents and Assemblies. Cambridge: Cambridge University Press. Steffani, W. (1979). Parlamentarische and präsidielle Demokratie. Opladen: Westdeutscher Verlag.

Stepan, Alfred, and Cindy Skach (1993). "Constitutional Frameworks and Democratic Consolidation: and Parliamentarism versus Presidentialism." World Politics 46, 1, 1-22.

Strøm, Kaare (1995). "Parliamentary Government and Legislative Organization.” Pp. 51-82 in Parliaments and Majority Rule in Western Europe, ed. Herbert Döring. New York: St. Martin's Press.

Strøm, Kaare (1997). "Democracy, Accountability, and Coalition Bargaining: The 1996 Stein Rokkan Lecture." European Journal of Political Research 31: 47-62.

Strøm, Kaare, and Stephen M. Swindle (n. d.). "The Strategic Use of Parliamentary Dissolution Powers." Typescript.

Timmermans, Arco and Rudy B. Andeweg (1997). "Die Niederlande: Immer noch Politik der gütlichen Einigung?" Pp. 443-500 in Koalitionsregierungen in Westeuropa, eds. Wolfgang C. Müller and Kaare Strøm. Vienna: Signum Verlag.

Tsebelis, George (1995). "Decisionmaking in Political Systems: Veto Players in Presidentialism, Parliamentarism, Multicameralism, and Multipartyism." British Journal of Political Science 25, 3, 289-325.

Verney, Douglas V. (1959). The Analysis of Political Systems. London: Routledge and Kegan Paul.

Weaver, R. Kent, and Bert A. Rockman, ed. (1993). Do Institutions Matter? Government Capabilities in the United States and Abroad. Washington, DC: The Brookings Institution. 


\section{Notes}

1. During the Age of Liberty (1718-82), Sweden developed a rudimentary version of parliamentary democracy that clearly predated the British experience. However, the Swedish experiment proved less efficient and sustainable than the later British one, and it is overwhelmingly the latter that has since become a model for the world.

2. Real-world parliamentary democracies vary in the extent to which they embody the principle that cabinet members must be parliamentary representatives. In fact, some systems make memberships in both branches of government incompatible (Andeweg and Nijzink 1995). However, such restrictions are most fruitfully considered to be modifications of the parliamentary principle (Hernes and Nergaard 1989).

3. For systems with bicameral legislatures, it suffices for the prime minister and cabinet to be accountable to the majority in one chamber. Empirically, this is typically the lower chamber. Regimes in which the prime minister and cabinet are accountable to both chambers, such as Italy, are the exception rather than the rule.

4. In their study of role perceptions among Swedish members of parliament, for example, Esaiasson and Holmberg note that "one alternative from the history of representational doctrine is missing, however - Burke's famous credo of 'the nation as a whole.' The reason for this is quite simply that Burke has been too successful; the norm that national interests come first is so well-established in most European parliaments that scholars consider it meaningless to probe parliamentary representatives on this matter" (Esaiasson and Holmberg 1996: 62).

5. Note that if we take the idea of singular agents to its logical extreme, the ideal-typical parliamentary democracy is also a unitary state (such as Britain or New Zealand or Sweden, but not Austria or Canada), with a unicameral parliament (such as the Nordic countries or, again, New Zealand).

6. Applied to the relationship between voters and parliamentarians, internal delegation implies a residence requirement for elected representatives. Although such rules, or at least norms, exist in some countries, they are not uniquely associated with parliamentarism. Since the introduction of civil service reforms, internal delegation is not generally a feature of the relationship between cabinet members and civil servants.

7. Tsebelis does not explicitly model the intra-coalitional games with partisan veto players. If such a model were constructed, his claim might be that all outcomes in which any partisan veto player receives a payoff lower than the status quo are out of equilibrium, since this veto player could threaten to defect from the coalition and thus block such a move. However, some such threats may not be credible. If they are not, and if that fact is common knowledge, the threat to defect should not deter a decisive subset of the coalition parties from imposing a decision that these parties otherwise prefer. In other words, the intra-coalitional solution that Tsebelis assumes may not be subgame perfect. 